\title{
Republicanism and the Political Economy of Democracy
}

\author{
David Casassas, Universitat de Barcelona \\ Jurgen De Wispelaere, McGill University
}

\begin{abstract}
Europe is experiencing rapidly accelerating poverty and social exclusion, following half a decade of financial crisis and austerity politics. The key problem behind Europe's malaise, in our view, is the economic disenfranchisement of large parts of its population in the winner-takes-all-society. This paper proposes that we examine the contribution of republican political theory as a distinctive approach that provides us with the conceptual and normative resources to reclaim what we call the political economy of democracy, the constellation of political and economic institutions aimed at promoting broad economic sovereignty and individuals' capacities to govern their own lives. In this paper we identify three key ideas that together constitute a distinctively republican approach to political economy: establish an economic floor, impose an economic ceiling to counter excess economic inequality, and democratize the governance and regulation of the main economic institutions.
\end{abstract}

Keywords: republicanism, domination, freedom, economic governance, inequality, basic income

Europe is in turmoil. A little more than half a decade of global financial crisis and a deep economic slump has seen large swaths of European citizens facing dire economic 
uncertainty and social exclusion. Austerity politics, an unimaginative knee-jerk response, continues to push already disadvantaged citizens across Europe into precariousness of a sort not seen since the 1930s. The brunt of the crisis is largely borne by those who are already struggling, with those at the top (the much maligned One Percenters) facing little or no adverse effects (Duménil and Lévy, 2013; Sayer, 2014). The resulting dramatic rise in inequality of economic opportunities, income and wealth is deeply problematic, morally and politically.

Proposals to keep economic precariousness and inequality in check, let alone reverse it (e.g., Piketty, 2014), rapidly find themselves gridlocked by a political and economic elite that has committed itself to riding out austerity policies at all cost for ideological rather than persuasive economic reasons (Stiglitz, 2010; Krugman, 2013). ${ }^{\mathrm{i}}$ The key problem behind Europe's malaise, in our view, is the economic disenfranchisement of large parts of its population in the winner-takes-all-society (Hacker and Pierson, 2010). ${ }^{\text {ii }}$ Against this backdrop, this paper proposes that we examine the contribution of republican political theory as a distinctive approach that provides us with the conceptual and normative resources to reclaim what we call the political economy of democracy, the constellation of political and economic institutions aimed at promoting broad economic sovereignty and individuals' capacities to govern their own lives (Malleson, 2014).

In the wake of Liberalism's complicity in bringing about the disastrous state of affairs we find ourselves in and Socialism's apparent failure to offer a persuasive alternative, political theorists have started to find inspiration with the earlier tradition of political thought associated with classical thinkers as diverse as Aristotle, Cicero, Machiavelli, Harrington, Rousseau, Paine, Robespierre, Jefferson, Madison, 
Wollstonecraft, and so on. This "republican turn" (White 2011) is explored today in the writings of, amongst others, Philip Pettit, Michael Sandel, Quentin Skinner, Richard Dagger, Frank Lovett, Stuart White, Antoni Domènech, Alex Gourevitch, Eric MacGilvray and John McCormick. The attraction of republicanism lies precisely in its insistence that the core value of being a free person - understood in Pettit's terms as being free from alien control or domination - entails the constitution of collective selfdetermination. Republicanism is simultaneously a theory of freedom and politics (Pettit, 1997), or put differently an account of freedom through politics. ${ }^{\text {ii }}$ This makes it an appealing starting point for examining the economic conditions of democratic governance.

The aim of our paper is to build on the work of the republican political theorists mentioned above by reconsidering the foundations of economic independence as a condition for freedom from domination and economic sovereignty. We begin in the next section to briefly outline the political theory of republicanism, as we understand it. Republicanism of course contains a variety of different ideas, and not all claims are endorsed by all who self-identify as republicans. Nevertheless, we hope our outline will sufficiently appeal to those who share our republican intuitions and concerns to form a basis upon which to build the next sections. The bulk of the paper examines three key ideas that together constitute the republican political economy of democracy. First, republican political economy must secure a universal and unconditional economic floor. Second, republican political economy must ensure that unequal economic opportunities or power does not impede a person's freedom from domination, by imposing an economic ceiling. Third, while economic floors and ceilings are important, republicanism nevertheless insists that economic sovereignty also be guaranteed in a 
more direct manner, by establishing robust democratic control over the economy. These three dimensions of economic governance each have spurred a considerable literature. The main contribution of our paper is to bring them together (albeit summarily) and to reclaim them as the foundation of a distinctively republican approach to political economy.

\section{Republicanism as political economy}

What is republican political economy? The starting point - as always - is the distinctive idea of freedom that informs republican political thought. ${ }^{\text {iv }}$ Republicanism adopts a notion of freedom that is distinct from the (more familiar) liberal ideal of freedom from interference (Pettit, 1997, 2001, 2012). Republican freedom requires not merely the absence of interference, but also protection against the mere possibility of interference. Liberal freedom says a person is only unfree when actually interfered with, but republicans entertain a more demanding view: a person who is placed in a position whereby a third party (individual or group) can impose their will on her is not considered free, even if that person refrains from actually interfering. Republican freedom requires that a person at all times is able to prevent or counter any attempt at undue interference, not merely its contingent absence. Republicanism and Liberalism also part ways in relation to what counts as interference. Liberals insist every form of interference is an infringement of freedom, whereas republicans believe that many forms of interference are in fact positively sanctioned by the person interfered with. Interference that is appropriately sanctioned by the individual or group that is subject to it cannot count as a constraint on freedom. Instead, republicans are only concerned with 
arbitrary interference which does not track the avowed or readily avowable interests of the person(s) interfered with. They are concerned with what Pettit $(2001,2012)$ calls alien control.

Republicanism doesn't merely give us an idea of what freedom is really about, but also an account of how to ensure that a free society - a society in which its citizens are all as equally free as possible - comes about. The republican conception of freedom as non-domination requires robust institutions that secure that all citizens are free from domination, both horizontal domination by others (dominium) and vertical state domination (imperium). Republican institutions come in three main forms. First, there is the legal regulation of rights (including property rights) as encompassed by the rule of law. Second, there is the constellation of economic resources (assets) that provide each citizen with a form of bargaining power to negotiate economic life on free and equal terms. Third, there is the set of political institutions that provide the opportunity of citizens to individually and collectively shape the institutional forms of social and economic life.

Recent republican thinking has been mostly devoted to exploring the rule of law, and its role in determining when interference counts as arbitrary (Pettit, 2009a; Lovett, 2014, List, 2006), or political mechanisms as a means for protecting citizens against arbitrary interference (Pettit, 2009b, 2010, 2012). Important as legal and political institutions are, republican political economy must extend its efforts farther to theorizing how politics and the law interacts with the economic sphere. This view has considerable pedigree in the history of political thought (Gargarella, 2012).

Almost all the great theorists of citizenship [...] have believed that in order to be a citizen of a polis, in order to be able to participate fully in public life, one needed to 
be in a certain socio-economic position.[...] People, it was said, could not act as citizens at all, or could not be expected to act well in the political sphere and to make adequate decisions, unless some attention was paid to matters of their wealth, their well-being and their social and economic status. (King and Waldron, 1988: 425-426)

The intricate interaction between economic and political institutions as a set of preconditions for republican freedom is what we refer to when we talk about republican political economy.

Historically and sociologically, the crucial institutional condition for the emergence of anything like republican freedom was property (Casassas, 2013; Domènech and Raventós, 2007). Property can be understood as durable control over a set of material resources or assets that leverages one's freedom in economic exchanges by effectively securing a form of bargaining power vis-à-vis other agents. In other words, property allows one the freedom to chose who to contract with and under what conditions. In extreme cases, it offers an exit option from those exchanges that are deemed alienating, exploitative or otherwise detrimental to one's freedom (Hirschman, 1970), ideally by opening the door to more congenial ones. ${ }^{\mathrm{v}}$

Of course the republican social ontology denies the existence of "free" markets of the sort stipulated by neoliberal ideology (Anderson, 2014). Instead, republicans adopt the classical political economy approach, as advocated most famously by Karl Polanyi (1944), by which economic exchanges are necessarily embedded in an institutional context (Wagner, 2005). Republican freedom is not about being independent from social and economic relations - republicans have little truck with libertarian atomistic individualism (Casassas and De Wispelaere, 2012) - but about 
being equally free within such relations. ${ }^{\mathrm{vi}}$ Republicans also recognize that the differential ownership relations of a variety of economic assets entails a world marked by significant social division, typically one that divides itself along something akin to class lines. At the same time, the republican ideal of economic freedom should not be confused with promoting "warm" economic relations, an economy based on "dense social ties" or an "economy of proximity". An overly romanticized reconstruction of republicanism along these lines (Dagger, 2006; Honohan, 2002; Sandel, 1996) detracts from the core concern with freedom from domination.

What counts as property in relation to securing economic freedom changes as society itself evolves. In the era of Classical Republicanism - extending from Ancient Greece and Rome to the America of Thomas Jefferson - socioeconomic independence was ensured by ownership of land, slaves, or livestock. In Commercial Republicanism associated with the Scottish Enlightenment but equally well capturing other forms of Atlantic or Italian Republicanism - the importance of real estate gives way to ownership of and control over installations and facilities (Marx" "means of production"), but also increasingly professional dexterities (human capital), opportunities to access profitable markets, and so on (Casassas, 2010, 2013). Moreover, we can trace a direct historical line between the $19^{\text {th }}$ century socialist emancipatory project and the political programs of $18^{\text {th }}$ century Scottish Enlightenment and $17^{\text {th }}$ century English Revolutionaries, with the Levellers and the Diggers at the left of the movement and, in its centre, moderate yet prominent figures like Harrington (Bernstein, 1963; Meek, 1954, 1977). Harrington aptly expresses the core of republican thought: "the man that cannot live upon his own must be a servant; but [he] that can live upon his own may be a freeman" (Harrington, 1992: 269). Two centuries later Marx, in his Critique of the Gotha Programme, equally 
powerful wrote that "the man who possesses no other property than his labor power must, in all conditions of society and culture, be the slave of other men who have made themselves the owners of the material conditions of labor. He can only work with their permission, hence live only with their permission" (Marx, 2008: 18). The socialist tradition can thus be seen as the modern heir of republican political thought (Domènech, 2004).

Philip Pettit's insistence that a free society must protect individuals from living a life under alien control is the latest installment of the same political doctrine.

Enjoying social freedom (having a status that guards you against arbitrary interference) means being proof or at least being relatively proof against [arbitrary] interference. No matter what your preferences are, and no matter what the feelings of others happen to be, your social standing will still serve you well. It will provide a protective field that makes you resistant to the arbitrary incursions of others. It will ensure that, intuitively, you are in control of what you choose. (Pettit, 2006: 136)

In sum, republican political economy requires both the descriptive study of the many variegated power inequalities in economic and social life, and their impact on individual freedom from domination. It also requires a normative analysis of the political measures that positively affect republican freedom by reducing economic dependence. Republicans aim to reclaim the classical political economy approach from Adam Smith to Karl Marx (Casassas, 2010, 2013). In the remainder of this paper we outline three practical components of a republican political economy: establishing an economic floor, 
imposing an economic ceiling, and universalizing democratic control in economic institutions.

\section{Establishing an economic floor}

The notion that republican freedom centrally depends on ensuring a measure of economic independence for all agents leads fairly straightforward to the requirement that we ought to establish an economic floor below which no one ought to fall. Such a floor serves a key purpose in equalizing power relations within economic exchanges, including guaranteeing the exit option that allows individuals to refuse any exchange they believe to be incompatible with their status as a free and equal citizen (Widerquist, 2013). But the idea of an economic floor is more complex than our intuition suggests, as we show in this section.

The first consideration we need to address concerns the form such a floor should take: what types of resources are suitable for achieving the task at hand? In principle, many economic resources could qualify. In South Africa, for instance, land restitution and (pre)distribution - has played a key role in promoting some measure of economic security (James, 2007; Walker, 2008). Many believe access to in-kind services or goods such as universal health care, free education or subsidized housing play a similar role. In his analysis of $19^{\text {th }}$ Century "labour republicans", Gourevitch (2011) relates how Thomas Skidmore claimed that the most suitable way to guarantee personal independence was a system of universal capital grants conferring upon all individuals reaching adulthood a one-off capital grant of their own financed from a tax on wealth. This represents one of the first formulations of basic capital schemes, prominently 
discussed at the turn of the $20^{\text {th }}$ Century (Ackerman and Alstott, 1999; Dowding, De Wispelaere and White, 2003). But the most familiar idea is no doubt the proposal to give each citizen a monthly basic income, independent of means test or work requirement (Van Parijs, 1995). The basic income proposal serves as a perfect example to illustrate the main features of an economic floor in the remainder of this section.

At what level should a basic income be pitched for it to promote republican freedom? The literature divides into two camps: those that advocate a basic income at subsistence level and those who believe even a basic income pitched significantly below subsistence (partial basic income) promotes important social goals. ${ }^{\text {vii }}$ For republicans the level of basic income depends on what is needed to have a real impact on one's economic bargaining power. An economic floor cannot be of such a low level that it could only contribute in a trivial manner to citizens' freedom as non-domination: republican freedom requires a substantial economic floor. At least three considerations come into play here

First, the republican idea of an economic floor is neither a linear concept, where each monetary unit translates in a corresponding unit of freedom, nor is it a rigid baseline separating those "below" from those "at or above" economic independence. The reason is that we can imagine different levels across economic spheres at which one has reached a critical threshold value of economic independence which then translates in increased republican freedom. The economic floor should be conceived as a step good that contributes to republican freedom in a discontinuous manner. A gradual increase in the economic floor - a low basic income, for instance - may have little or no direct effect on a person's republican freedom until it reaches a tipping point, at which point a "higher stage" of republican freedom comes about. An economic floor pitched 
below such a tipping point or threshold entails that citizens are perhaps better off in terms of well-being, but not necessarily more free in the republican sense.

Second, the satisfaction of basic material needs constitutes a rather obvious tipping point, as it would make it possible (or more likely) for citizens to exit social relations that render them unfree. But this may be too demanding a requirement, for it is not clear whether republicans would have to insist on the "freedom to say no" to any and all economic exchanges (as implied, for instance, by Widerquist, 2013). Such a highly demanding conception of freedom will command precious little support in the real world. On the republican view, a substantial measure of economic independence must not necessarily entail the option to exit the labour market altogether. ${ }^{\text {viii }}$ On the contrary, broadening the range of economic options such that citizens are no longer trapped in a particular job but instead have access to a sufficient range of feasible options to move between jobs could be fully compatible with the demands of republican freedom. Even a partial basic income may allow someone to exit a particularly demeaning job to take up a lesser paid or even part-time position that is more fulfilling, and for that reason preferred. In short, the level of the economic floor required by republican political economy varies in line with the alternatives society makes available. ${ }^{\mathrm{ix}}$

Third, there are many reasons to think that an economic floor really only promotes republican freedom in conjunction with a wider set of public policies (a "package of measures"), including in-kind benefits such as access to health care and education, housing policies, care policies, regulations pertaining to pension provision, employment directives like a decent minimum wage, and so on. To use a phrase inspired by the debate on the Rawlsian basic liberties, we can distinguish between the "economic 
floor" and the "worth of the economic floor". The former is determined by the mere size of the basic income, but the latter is determined by the broader policy context in which the dividend operates. Obviously, an economic floor within a comprehensive protective policy context enhances republican freedom more than an institutional framework where an economic floor - even a high basic income - constitutes the sole mechanism conferring the weak a safety net. For this reason republicans must denounce Charles Murray's (2006) proposal to replace all welfare state programs with a single basic income scheme. Having to buy all kind of social services in the market - where, for instance, prices of health insurances grow with risk because of "adverse selection" and risks themselves are no longer properly pooled - might rapidly turn the economic floor into an irrelevant measure for promoting republican freedom.

These three considerations demonstrate that determining the precise level of the economic floor, consistent with republican concerns for freedom from domination, is a complicated matter. There exists considerable scope for political debate in this regard, and this is to be welcomed. However, whatever the level, for the economic floor to play its part in securing republican freedom it must be unconditionally granted to each citizen. To impose conditions means accepting that at least some citizens may end up with a standard of living that threatens their republican freedom. Poverty and economic insecurity are readily acknowledged to impede one's freedom: dire need is the main reason why individuals sign up to "free exchanges" that are exploitative or oppressive and often leave them barely better off than before. ${ }^{x}$ But the very policies aimed at redressing poverty may become vehicles of arbitrary interference as soon as they impose conditions on those seeking them (Standing and Jhabvala, 2010). Whereas poverty makes a person vulnerable to dominium, conditional support puts her at risk of 
imperium. The only remedy is to make the economic floor unconditional. The basic income proposal in its purest form represents the best example of how to institute an economic floor: it requires no proof of income or assets, no requirement of work or even willingness to work, no explanation of living arrangement, and no control of how the money is spent.

Let us now turn to a final key feature of the economic floor in republican political economy. Building on Richard Titmuss' classic analysis, the programs of the modern welfare state typically take the form of ex post facto remedies. The main purpose of residual support, after all, is to address social problems associated with unemployment, disability and ill health, poverty and economic insecurity after the fact. In recent years, however, much policy attention has begun to rethink the role of social support in preventing adverse events from occurring in the first place or, where this proves unavoidable, in mitigating their impact at an early stage (Sinfield, 2012; Diamond and Liddle, 2011). The republican idea of an economic floor takes a similar preemptive approach to empowering individuals to negotiate the vagaries of economic life. While ex ante prevention of social ills is warranted on both individual welfare and social efficiency grounds, the distinctive republican contribution here is couched in terms of securing the wherewithal for each person to live her life on her own terms "without permission", in the Marxian phrase mentioned earlier.

The ex ante prevention or pre-distribution approach is not a novel idea. It echoes the idea of a property-owning democracy, as it was understood by Jefferson in late $18^{\text {th }}$ Century and expounded in more recent days by James Meade (1964) and John Rawls (2001) (O’Neill and Williamson, 2012; White and Seth-Smith, 2014). The following passages by Meade and Rawls are extremely telling. 
The essential feature of [a property-owning democracy] would be that work had become rather more a matter of personal choice. The unpleasant work that had to be done would have to be very highly paid to attract to it those whose tastes led them to wish to supplement considerably their incomes from property. At the other extreme, those who wished to devote themselves to quite uncommercial activities would be able to do so with a reduced standard of living, but without starving in a garret. (Meade, 1964: 40)

To which Rawls adds: "[t]he idea is not simply to assist those who lose out through accident or misfortune (although this must be done), but instead to put all citizens in a position to manage their own affairs and take part in social cooperation on a footing of mutual respect under appropriately equal conditions" (Rawls, 2001: 139). Republicans push for unconditional ex-ante public policy measures on similar grounds: where expost measures lock citizens into a socioeconomic status quo - namely, capitalist markets in one or other form - universal and unconditional ex-ante measures empowers them from the start to engage on mutually agreed terms in the productive sphere.

\section{Imposing an economic ceiling}

An economic floor is a key requirement for securing freedom from domination in a republican political economy, but it paints only part of the picture. As we already mentioned in the previous section, the value of an economic floor - its effective capability to robustly protect a citizen's economic independence - in large part depends on the broader socio-economic context. Chiefly amongst those is the power differentials 
associated with vast inequalities of income and wealth. In this section we argue that a concern with promoting citizens' republican freedom requires imposing an economic ceiling, which we understand roughly as a limit imposed on the differential economic power that derives from accumulations of wealth.

The rationale underlying this requirement is straightforward. Vast accumulations of economic power tend to go hand in hand with the capacity of some to turn economic life into an oligarchic game by creating barriers to market entry, by fixing prices in a predatory way, by controlling the use of strategic resources (including investment; White, 2011), by hampering autonomy and self-realization in the workplace, and so on. Economic empowerment through a basic income or similar floor of resources constitutes a significant achievement from a republican point of view, but it nevertheless falls short of realizing republican freedom when powerful actors retain the power to determine the rules of the game, which in turn entails the capacity to exercise significant economic control over others (McCormick, 2011).

The idea of an economic ceiling comes in two main types: a Rousseauian and a Rooseveltian variation. The first manner in which to impose a ceiling consists of directly limiting the range of economic inequality. Without having to endorse strict equality of resources, republicans are rightly concerned about a society in which, through a variety of inventive schemes, the share of per capita earnings of employers and top management dwarfs that of ordinary workers. According to Pizzigati (2009: 41) only a generation ago "CEO pay averaged 40 times worker take-home. The gap in 2007: 344 times." And there is no sign of this trend abating. Republicans share the Rousseauian view that there are moral grounds for insisting that earnings differentials should remain within a reasonable limit, proportional to the work that has been 
performed. Excessive inequality leads to a fractured society in which trust and social solidarity are hard to sustain. Pettit is adamant that "the ideal of equal status freedom [...] puts significant constraints on how large material inequalities can be" (Pettit, 2012: 298).

Raising minimum wages and limiting top salaries are two familiar policies that contribute to keeping economic inequality in check (Pizzigati, 2004, 2012), but an effective economic ceiling likely requires a wider range of interventionist policies. Peter Taylor-Gooby recommends "measures to curb incomes at the top end through reforms to remuneration systems and possibly maximum wage legislation" as key requirements to combat inequality (Taylor-Gooby, 2013: 40). Or consider James Meade's model of a "partnership economy", a comprehensive Rousseaunian program consisting of four elements: pay within the firm is determined by profit-sharing and revenue-sharing mechanisms; wealth is taxed as it passes onto the next generation (wealth tax); the community owns a large share of the nation's productive assets; and the return on the community fund pays for a uniform grant to all citizens (Meade, 1989; White, 2012). Thomas Piketty's (2014) well-known proposal for a global tax on wealth to prevent soaring inequality also addresses Rousseauian concerns, while Ingrid Robyens (2015) has recently offered a philosophical defense of this approach, which she dubs "Limitarianism".

Under current political conditions, however, measures that directly restrict economic inequality by imposing a limit on top earnings or profits may prove difficult to implement. The second Rooseveltian model includes measures that allow economic inequality to emerge, but impose a strong regulatory ceiling on how vast economic wealth can arbitrarily interfere in citizens' lives. The United States has a long - albeit 
lost - tradition of regulating powerful social and economic actors to prevent them from eroding the freedom of ordinary citizens. Regulations conceived during the progressive era strengthened the foundations of democracy by institutionally confining economic power (Beard and Beard, 1939; Pizzigati, 2012). In telling rhetoric, Franklin Delano Roosevelt explicitly accused the so-called "economic monarchs" of imposing a "new industrial dictatorship" (Leuchtenburg, 1995: 125). Roosevelt regarded oligarchies that foster the concentration of economic and political power as natural enemies of democracy, and the true culprits of the Great Depression (Sunstein, 2004). This opened the door for Thurman Arnold's resolute action, as the Head of the Justice Department's Antitrust Division between 1938 and 1943, against powerful actors such as General Electrics or The Aluminium Company of America (Leuchtenburg, 2009).

Excessive wealth and economic power provides both the resources and the motivation to exert disproportionate political influence (Winters and Page, 2009). The economically powerful exercise their influence through a variety of mechanisms: lobbying government officials; contributing to expensive political campaigns; influencing public opinion through television, print media, and increasingly online social media; and the constitutional imposition of rules "beyond the reach of simple majority control" all aimed at reifying economic power (Winters and Page, 2009: 743). Hacker and Pierson (2010) capture this point well. Rather than a game between equally endowed actors, they argue, actual politics should be seen as "organized combat" characterized by the systematic exercise of power and influence by business elites who favor winner-take-all outcomes. "On the one side, government profoundly influences the economy through an extensive range of policies that shape and reshape markets. On the other side, economic actors - especially when capable of sustained collective action 
on behalf of shared material interests - have a massive and ongoing impact on how political authority is exercised" (Hacker and Pierson, 2010: 196). Rooseveltian public control over powerful economic actors offers a countermeasure to winner-take-allpolitics.

Republicans will endorse whichever strategy - or combination of strategies works best, although there are reasons to think that an ex-ante Rousseauian approach of preventing economic power by limiting income and wealth accumulation and inequality may be preferable over an ex-post attempt to restrict its negative consequences through Rooseveltian regulation. Through its insistence on imposing an economic ceiling, republican political economy finds itself very much in line with the classical political economy view that state intervention must put an end to the privileges of modern employers, who in many cases are nothing less than "rentiers" (Casassas, 2013). We can understand Smith, Ricardo and even Marx as furthering a political ideal within the realm of manufacture and commerce by which everyone must be remunerated according to their productive contribution - including reasonable returns to capital investment but where rents of any type (land or capital) - the result of unproductive labour - are to be avoided (Milgate and Stimson, 1991). In a similar vein, Keynes (2007) suggested nothing less than the "euthanasia of rentiers", for rentiers severely limit people's participation in the economic sphere and produce injustice and inefficiency by controlling entire markets and economies. They must be fiscally destroyed, Keynes writes in his General Theory. Adam Smith, for his part, had already argued that in a prosperous economy profits are always low: when economic inclusion and participation are high, prices tend to decrease; and those who have incentives to prevent this from happening must be politically controlled (Casassas, 2010, 2013). The failure to do 
precisely that is a large part of the explanation for the speculative origins of the current crisis of Capitalism (Varoufakis, 2011; Engelen et al, 2012; Sayer, 2014).

\section{Democratizing economic governance}

We now move onto the last step in our outline of a republican political economy of democracy. The final requirement to secure republican freedom is to both broaden and deepen the scope of economic governance by increasing citizen participation in determining the rules shaping our economy. Economic governance is broadened when more citizens are actively participating in setting economic regulation and policy. Economic governance is deepened when more aspects of the decision-making process become available for citizen participation.

Democracy is central in republican political thought (Pettit, 2012). This follows from the requirement that in a modern society at all times intervention must remain under the control of those at risk of being interfered with (McCormick, 2011). Fama and Jensen's (1983) classic study demonstrates that the concept of ownership entails both a "benefit" and a "control" dimension: those benefiting from owning a resource are not necessarily the same as those controlling it; nor is the value of "control" for an owner reducible to that of its "benefit". Contemporary political thinking perhaps has focused too much on the benefit dimension and failed to fully grasp the importance of control for free agency; a failure republicans are keen to redress.

This is why Alex Gourevitch (2013) is correct in arguing that a mere focus on an economic floor (in the form of an unconditional basic income) can never be sufficient to guarantee full republican freedom. Exit options at best offer a partial answer to 
structural domination (Hsieh, 2005; Gourevitch, 2013; also Lovett, 2012; Anderson, 2014), as does relying on improving the competitiveness of markets (Taylor, 2013). Even if market competition alleviates republican domination, the existence of large firms and the incorporation of workers into a governance structure that precludes negotiation of the terms of contract produce a source of domination that is different from market freedom (Anderson, 2014). Consequently, if the goal of a republican political economy of democracy is the empowerment of citizens to exercise effective self-determination in the economic spheres of production, distribution, consumption, and even investment (White, 2011; Ott, 2014), market freedom needs to be complemented with increased democratic participation at all levels of economic organization.

The republican democratization project proceeds in two stages. In the first instance, republicans follow the lead of Marx in demanding "collective control over the means of production", for without the capacity to co-determine the terms under which we engage with each other as social and economic agents republican freedom cannot but remain a mirage. Republicanism, then, represents "the hope that it is possible, at least under some circumstances, for a people to shape its own political destiny, that we need not embrace the tenets of economic determinism" (MacGilvray, 2011: 19). But republican political economy also "individualizes" the Marxian insight in important ways, for collective control always retains the threat of vertical domination (imperium) unless the collective itself is subject to democratic control - in fairness, Marx himself was very much aware of this threat. Economic governance republican-style does not merely address the problem of powerful economic interests of selective individuals or 
corporations, but needs to find ways to radically democratize the participation of each single individual in the decision process.

In the economic sphere this leads us straight to the intricate debate on workplace democracy, which has recently seen a revival in the republican political theory (Hsieh, 2005; Gourevitch, 2013; González-Ricoy, 2014; Anderson, 2014; more generally Schweickart, 2011). In brief, the case for republican workplace democracy hinges in the first instance on an assessment of the exit costs associated with leaving the labor market or even a particular job, which those focusing entirely on securing a basic income in order to facilitate exit often fail to appreciate (Widerquist, 2013). With exit being more difficult, next we must inevitably devote our attention to the many ways in which employment contracts typically entail domination, understood as a relation of arbitrary inference on the part of employers over employees. Examples include the one-sided direction of workers to certain tasks or limiting their performance; scheduling and rescheduling of time and location; favoritism in allocating work, overtime, compensation and promotion; verbal and physical abuse in supervision; and so on (Hsieh, 2005; González-Ricoy, 2014). This type of domination is often taken to be partand-parcel of managerial privilege and a necessary condition for efficient management. Republicans disagree and insist that cooperative forms of management are both more efficient and conducive to protecting republican freedom within the firm. While the precise form of workplace democracy remains a topic of continued debate, a consensus emerges that rebalancing the negotiation of working conditions through robust economic participation of workers within the firm is a requirement for republican freedom in the economic sphere. ${ }^{\mathrm{xi}}$ 
At the level of political institutions, this democratic ideal requires much more than a Schumpeterian process of selecting elite rulers, and equally it must avoid the economistic model of the citizen as a mere consumer of political goods. The republican alternative seeks its inspiration in a combination of democratic deliberation and democratic contestation. The republican literature discusses a variety of institutional mechanisms aimed at broadening and deepening democratic control in concrete contexts. ${ }^{\text {xii }}$ Some of these measures affect the "electoral dimension" and are primarily concerned with assuring adequate representation and accountable delegation (Pettit, 2000, 2009b, 2010; Mansbridge, 2009). Other mechanisms operate in the "contestatory dimension", proposing a range of non-electoral devices from courts and arbiters over independent audits to emancipatory social movements (Pettit, 2000, 2012; Niederberger and Schink, 2013). The recent surge in worldwide popular protest à la Occupy takes pride of place in a republican theory of contestation (Malleson, 2014). But contestation always requires political empowerment, and its success in democratizing economic governance in turn depends on citizens also being economically empowered, closing the virtuous circle of economic floor, economic ceiling and democratic governance. This last point also restates the key republican insight that economic governance is political throughout - "political economy", in the classic sense of the term.

\section{Conclusion}

In this paper we offer a brief outline of the republican political economy of democracy. Republican freedom from domination or alien control requires institutions and policies that offer robust protection against both horizontal and vertical forms of domination. 
Risk of domination in a modern society is strongly associated with socio-economic position: republican freedom requires a significant level of economic independence as a countermeasure against a capitalist economic sphere rife with domination. Republican political economy provides both a descriptive account of the many forms of domination in economic life, and a normative account of why and how to counteract them. In this paper we suggest that a republican political economy must simultaneously establish an economic floor, impose an economic ceiling to counter excess economic inequality, and democratize the governance and regulation of the main economic institutions.

\section{Acknowledgements}

Previous versions of this paper were presented at the $12^{\text {th }}$ Annual North America Basic Income Guarantee Congress (New York), $2^{\text {nd }}$ TRAMOD International Conference on "Economic Modernity in the 21st Century: Markets, Democracy, Solidarity" (Barcelona), $14^{\text {th }}$ Congress of the Basic Income Earth Network (BIEN) (Munich), 22 ${ }^{\text {nd }}$ World Congress of Political Science (IPSA) (Madrid) and the 2012 Annual Conference of the Association for Legal and Social Philosophy (Belfast). We are grateful to participants at these events, and to Bob Goodin, Rubén Lo Vuolo, Peter Wager and the members of the 'Trajectories of Modernity' (TRAMOD) Research Project (University of Barcelona) for helpful criticism. The research leading to these results has received financial support from the European Research Council under the European Union's Seventh Framework Programme (FP7/2007-2013) / ERC grant agreement no. 249438 -

TRAMOD (Casassas) and from the Montreal Health Equity Research Consortium, McGill University (De Wispelaere). 


\section{References}

Ackerman B and Alstott A (1999) The Stakeholder Society. New Haven: Yale University Press.

Anderson E (2014) Equality and Freedom in the Workplace: Recovering Republican Insights. Social Philosophy and Policy, forthcoming.

Beard CA and Beard MR (1939) America in Midpassage. New York: Macmillan.

Benz, M and Frey BS (2008) Being Independent is a Great Thing: Subjective Evaluations of Self-Employment and Hierarchy. Economica, 75(298): 362-83.

Bernstein E (1963) [1895] Cromwell and Communism. Socialism And Democracy in the Great English Revolution. London: George Allen \& Unwin.

Block F and Somers M (2014) The Power of Market Fundamentalism: Karl Polanyi's Critique. Cambridge, MA: Harvard University Press.

Casassas D (2007) Basic Income and the Republican Ideal: Rethinking Material Independence in Contemporary Societies. Basic Income Studies, 2(2): 1-7.

Casassas D (2010) La ciudad en llamas: la vigencia del republicanismo comercial de Adam Smith, Barcelona: Montesinos.

Casassas D (2013) Adam Smiths' Republican Moment: Lessons for Today's Emancipatory Thought. Economic Thought. History, Philosophy and Methodology, 2(2): 1-19.

Casassas D and De Wispelaere J (2012) The Alaska Model: A Republican Perspective. In: Widerquist K and Howard MW (eds) Alaska's Permanent Fund Dividend. Examining Its Suitability as a Model. New York: Palgrave Macmillan. 
Dagger R (2006) Neorepublicanism and the Civic Economy. Politics, Philosophy \& Economics, 5(2): 151-73.

Diamond P and Liddle R (2011) Aftershock: the post-crisis social investment welfare state in Europe. In Morel N, Palier B and Palme J (eds.) Towards A Social Investment Welfare? Ideas, Policies and Challenges. Bristol: Policy Press.

Domènech A (2004) El eclipse de la fraternidad. Una revisión republicana de la tradición socialista, Barcelona: Crítica.

Domènech A and Raventós D (2007) Property and Republican Freedom: An Institutional Approach to Basic Income. Basic Income Studies, 2(2): 1-8.

Dowding K, De Wispelaere J and White S (eds.) (2003) The Ethics of Stakeholding. Bastingstoke: Palgrave.

Duménil G and Lévy D (2013) The Crisis of Neoliberalism. Cambridge, MA: Harvard University Press.

Eder K (2014) The EU in search of its people: The birth of a society out of the crisis of Europe. European Journal of Social Theory 17(3): 219-237.

Engelen E et al (2012) After the Great Complacence: Financial Crisis and the Politics of Reform. Oxford: Oxford University Press.

Fama EF and Jensen MC (1983) Separation of Ownership and Control. Journal of Law and Economics, 26(2): 301-25.

Freeman RB and Rogers J (2006) What Workers Want. (Updated edition) Ithaca: Cornell University Press and London: Russell Sage Foundation.

Gargarella R (2012) Basic Income and the Constitution. In: Lo Vuolo RM (ed.) Citizen's Income and Welfare Regimes in Latin America: From Cash Transfers to Rights. New York: Palgrave Macmillan. 
González-Ricoy I (2014) The Republican Case for Workplace Democracy. Social Theory and Practice, 40(2): 232-54.

Gourevitch A (2011) Labor and Republican Liberty. Constellations. An International Journal of Critical and Democratic Theory, 18(3): 431-454.

Gourevitch, A. (2013) Labor Republicanism and the Transformation of Work. Political Theory 41(4): 591-617.

Hacker JS and Pierson P (2010) Winner-Take-All Politics: Public Policy, Political Organization, and the Precipitous Rise of Top Incomes in the United States. Politics \& Society, 38(2): 152-204.

Harrington J (1992) [1656-1747] The Commonwealth of Oceana and A System of Politics. (edited by Pocock JGA) New York: Cambridge University Press.

Hirschman AO (1970) Exit, Voice, and Loyalty. Responses to Decline in Firms, Organizations, and States. Cambridge, MA: Harvard University Press.

Honohan I (2002) Civic Republicanism. London \& New York: Routledge.

Hsieh N (2005) Rawlsian Justice and Workplace Republicanism Social Theory and Practice 31(1): 115-42.

Innerarity D (2014) What kind of deficit? Problems of legitimacy in the European Union. European Journal of Social Theory 17(3): 307-325.

James D (2007) Gaining Ground? 'Rights' and 'Property' in South African Land Reform. London \& New York: Routledge.

Keynes JM (2007) [1936] The General Theory of Employment, Interest and Money. Basingstoke: Palgrave Macmillan.

King D and Waldron J (1988) Citizenship, Social Citizenship and the Defence of Welfare Provision. British Journal of Political Science, 18: 415-43. 
Krugman P (2013) End This Depression Now! New York: WW Norton.

Leuchtenburg WE (1995) The FDR Years: on Roosevelt and His Legacy. New York: Columbia University Press.

Leuchtenburg WE (2009) Franklin D. Roosevelt and the New Deal: 1932-1940. New York: Harper Perennial.

List C (2006) Republican Freedom and the Rule of Law. Politics, Philosophy \& Economics, 5(2): 201-20.

Lovett F (2010) A General Theory of Domination and Justice. New York: Oxford University Press.

Lovett F (2014) A Republican Theory of Adjudication. Res Publica, OnlineFirst: $10.1007 / \mathrm{s} 11158-014-9257-7$.

MacGilvray E (2011) The Invention of Market Freedom. Cambridge: Cambridge University Press.

Malleson T (2014) After Occupy: Economic Democracy for the $21^{\text {st }}$ Century. New York: Oxford University Press.

Mansbridge J (2009) A "Selection Model" of Political Representation. Journal of Political Philosophy, 17(4): 369-98.

Marsden D (2010) The paradox of performance-related pay systems: why do we keep adopting them in the face of evidence that they fail to motivate? In: Hood C, Margetts $\mathrm{H}$. and $6 \mathrm{P}$ (eds.) Paradoxes of Modernization: Unintended Consequences of Public Policy Reforms. Oxford: Oxford University Press.

Marx K (2008) [1875] Critique of the Gotha Program. Rockville, Maryland: Wildside Press. 
McCormick JP (2011) Machiavellian Democracy. New York: Cambridge University Press.

Meade J (1964) Efficiency, Equality, and the Ownership of Property. London: George Allen and Unwin.

Meade J (1989) Agathatopia: The Economics of Partnership. Aberdeen: Aberdeen University Press.

Meek RL (1954) The Scottish Contribution to Marxist Sociology. In: Saville J (ed.) Democracy and the Labour Movement: Essays in Honor of Donna Torr. London: Lawrence \& Wishart.

Meek RL (1977) Smith and Marx. In Meek RL, Smith, Marx and After: Ten Essays in the Development of Economic Thought. London: Chapman \& Hall.

Milgate M. and Stimson SC (1991) Ricardian Politics. Princeton: Princeton University Press.

Murray C (2006) In Our Hands: A Plan to Replace the Welfare State. Washington, DC: American Enterprise Institute for Public Policy Research.

Niederberger A and Schink P (eds.) (2013) Republican Democracy: Liberty, Law and Politics, Edinburgh: Edinburgh University Press.

O'Neill M and Williamson T (eds.) (2012) Property-Owning-Democracy: Rawls and Beyond. Oxford: Wiley-Blackwell. 
Ott J (2014) When Wall Street Met Main Street: The Quest for an Investors' Democracy. Cambridge, MA: Harvard University Press.

Outhwaithe W (2014) The future of European democracy. European Journal of Social Theory 17(3): 326-342.

Pettit P (1997) Republicanism: A Theory of Freedom and Government. New York: Oxford University Press.

Pettit P (2000) Democracy, Electoral and Contestatory. In: Shapiro I and Macedo S (eds.) Designing Democratic Institutions. New York: New York University Press.

Pettit P (2001) A Theory of Freedom: From the Psychology to the Politics of Agency. Oxford: Oxford University Press.

Pettit P (2006) Freedom in the Market. Politics, Philosophy \& Economics, 5(2): 131-49. Pettit P (2007) A Republican Right to Basic Income? Basic Income Studies, 2(2): 1-8.

Pettit, P. (2009a) Law and Liberty. In: Besson S and Martí JL (eds.) Legal Republicanism: National and International Perspectives. Oxford: Oxford University Press.

Pettit, P. (2009b) Varieties of Public Representation. In Shapiro I et al (eds.) Political Representation. Cambridge: Cambridge University Press.

Pettit, P. (2010) “The Power of the Democratic Public" In: Gotoh R and Dumouchel P (eds.) Against Injustice: The New Economics of Amartya Sen. Cambridge: Cambridge University Press.

Pettit P (2012) On the People's Terms: A Republican Theory and Model of Democracy. Cambridge: Cambridge University Press.

Piketty T (2014) Capital in the Twenty-First Century. Cambridge, MA: Harvard University Press. 
Pizzigati S (2004) Greed and Good: Understanding and Overcoming the Inequality That Limits Our Lives. New York: The Apex Press.

Pizzigati S (2009) The Corporate Pay Gap: Do We Need a Maximum Wage? Perspectives on Work, 12(1-2): 40-2.

Pizzigati S (2012) The Rich Don't Always Win: The Forgotten Triumph over Plutocracy that Created the American Middle Class, 1900-1970. New York: Seven Stories Press.

Polanyi K (1944) The Great Transformation. The Political and Economic Origins of Our Time. Boston: Beacon Press.

Raventós D (2007) Basic Income: The Material Conditions of Freedom. London: Pluto Press.

Rawls J (2001) Justice as Fairness: A Restatement. Cambridge, MA: Belknap Press.

Robeyns I (2015) Limitarianism. NOMOS, forthcoming.

Sandel M (1996) Democracy's Discontent: America in Search of a Public Philosophy. Cambridge, MA: Harvard University Press.

Satz D (2010) Why Some Things Should Not be For Sale: The Moral Limits of the Market. New York: Oxford University Press.

Sayer A (2014) Why We Can't Afford The Rich. Bristol: Policy Press.

Schweickart D (2011) After Capitalism (2nd ed.), Lanham, MD: Rowman \& Littlefield. Simon WH (1991) Social-Republican Property. UCLA Law Review, 38(6): 1335-414. 
Sinfield A (2012) Strengthening the prevention of social insecurity. International Social Security Review 65(4): 89-106.

Somers M and Block F (2005) From Poverty to Perversity: Ideas, Markets, and Institutions over 200 Years of Welfare Debate. American Sociological Review, 70(2): $260-87$.

Standing G (2011) The Precariat: The New Dangerous Class. London: Bloomsbury.

Standing G and Jhabvala R (2010) Targeting to the 'poor': Clogged pipes and bureaucratic blinkers. Economic \& Political Weekly, 45(26-27): 239-46.

Stiglitz JE (2010) Freefall: America, Free Markets, and the Sinking of the World Economy. New York: WW Norton.

Sunstein C (2004) The Second Bill of Rights: FDR's Unfinished Revolution, And Why We Need It More Than Ever. New York: Basic Books.

Taylor RS (2013) Market Freedom as Antipower. American Political Science Review, 107(3): 593-602.

Taylor-Gooby P (2013) Why Do People Stigmatise the Poor at a Time of Rapidly Increasing Inequality, and What Can Be Done About It? The Political Quarterly, 84(1): 31-42.

Van Parijs P (1995) Real Freedom for All: What (if Anything) Can Justify Capitalism? Oxford: Oxford University Press.

Varoufakis Y (2011) The Global Minotaur: America, The True Origins of the Financial Crisis and the Future of the World Economy. London \& New York: Zed Books.

Wagner P (2005) The Political Constitution of Contemporary Capitalism. In: Joerges C, Stråth B and Wagner P (eds.) The Economy as a Polity. The Political Constitution of Contemporary Capitalism. London: UCL Press. 
Wagner P (2012) Modernity: Understanding the Present. London: Polity Press.

Walker C (2008) Landmarked: Land Claims and Land Restitution in South Africa. Athens, OH: Ohio University Press.

White S (2011) The Republican Critique of Capitalism. Critical Review of International Social and Political Philosophy, 14(5): 561-79.

White S (2012) Property-Owning Democracy and Republican Citizenship. In: O’Neill $\mathrm{M}$ and Williamson T (eds.) Property-Owning-Democracy: Rawls and Beyond. Oxford: Wiley-Blackwell.

White S and Seth-Smith N (eds.) (2014) Democratic Wealth: Building a Citizens' Economy. London: openDemocracy.

Widerquist K (2013) Independence, Propertylessness, and Basic Income: A Theory of Freedom as the Power to Say No. New York: Palgrave Macmillan.

Winters JA and Page B.I. (2009) Oligarchy in the United States? Perspectives in Politics, 7(4): 731-51.

David Casassas is Lecturer in Sociology at the University of Barcelona. He holds a $\mathrm{PhD}$ in sociology from the same university, with a thesis on the republican roots of Adam Smith and classical political economy. He has conducted postdoctoral research on republican political theory, basic income and the history of thought at the Hoover Chair of Economic and Social Ethics (Université Catholique de Louvain, Belgium), the Centre for the Study of Social Justice (University of Oxford) and the Group in Analytical Sociology and Institutional Design (Universitat Autònoma de Barcelona). His book on Adam Smith's commercial republicanism appeared with Montesinos, Barcelona, in 2010.

David Casassas, Department of Sociological Theory, Philosophy of Law and Methodology of Social Sciences, Universitat de Barcelona, Avgda. Diagonal 690, 08034 Barcelona, Spain.

Email: dcasassas@ub.edu.

Jurgen De Wispelaere is a Research Fellow at the McGill Institute for Health and Social Policy. An occupational therapist turned political theorist, he previously taught at Trinity College Dublin and University College Dublin. His main research interest is in 
political theory applied to public policy and institutional design. Recent publications on unconditional basic income have appeared in Journal of Public Policy, Politics and Political Studies.

\section{Notes}

\footnotetext{
i See especially the work by Fred Block and Margaret Somers on the "ideational embeddedness" of freemarket fundamentalism (Somers and Block, 2005; Block and Somers, 2014).

ii In this paper we refrain from discussing one key dimension of the Euro Crisis, namely the extent to which the economic, fiscal and political regulatory framework of the European Union, and the fragile balance between Euro-central and Euro-petal forces prevents the constitution of a Europe-wide demos impossible. The social processes mediated through the political reality of the EU are important factors in explaining the failure of social movements to capture the "critical moment" presented by the Euro crisis (Eder, 2014; also Innerarity, 2014; Outhwaithe, 2014).

iii Republicanism here also intersects with the broader civilization project revolving around individual and collective autonomy that Wagner (2012) has argued characterizes modernity.

${ }^{\text {iv }}$ For a more ecumenical list of republican values, see White (2011).

${ }^{v}$ Recent economic research has demonstrated a clear correlation between independence (in the labour market) and subjective wellbeing (Bentz and Frey, 2008).

vi " $[\mathrm{I}] \mathrm{n}$ case it were true that only economic independence guaranteed political independence, then it was necessary to ensure economic independence to all” (Gargarella, 2012: 241).

vii In addition, there are those who remain deliberately agnostic about the level of the grant. Philippe Van Parijs (1995) famously proposes a basic income pitched at the highest sustainable level, which he acknowledges may even be equal to zero. However, from a republican perspective, too low a level of the highest sustainable economic floor may not be worth the effort in securing it, particularly if other measures are more likely to better promote the kind of socioeconomic independence that is so closely related to the progress of republican freedom (Casassas and De Wispelaere, 2012).

viii This is in line with those basic income advocates who regard it as a key instrument in liberating citizens within (not necessarily from) the world of work (Van Parijs, 1995; Standing, 2011).

ix One of the controversial aspects of introducing a basic income concerns the motivation to work. Industrial relations research casts doubt on the effectiveness of performance-pay schemes (Marsden, 2010), suggesting alternative motivation strategies would be more efficient. The traditional economic model nevertheless continues to operate with the notion that alternative sources of income will inevitably reduce a individual's willingness to work.

${ }^{x}$ For instance, fear of exploitation is one of the reasons for continued resistance against instituting a market in organs, even in the face of a growing deficit of available organs for transplantation purposes (Satz, 2010).

${ }^{x i}$ Survey research also shows that inclusive decision-making at work is what workers themselves value (Freeman and Rogers, 2006).

xii Political institutions must satisfy Lincoln's three demands: they should be "for the people", "by the people", and "of the people" (Pettit, 2012).
} 